\title{
Electoral Institutions and the Manifestation of Bias: The Effect of the Personal Vote on the Representation of Women
}

\section{Melody Ellis Valdini}

\section{Portland State University}

7 he "personal vote" refers to "that portion of a candidate's electoral 1 support which originates in his or her personal qualities, qualifications, activities, and record" (Cain, Ferejohn, and Fiorina 1987, 9). The presence of a personal vote in an electoral system means that the person up for election matters, not just the candidate's party. Cain, Ferejohn, and Fiorina go so far as to refer to it as "relationships between the represented and representatives," claiming that these relationships are more "personal, particularistic, and idiosyncratic than in other kinds of systems" (8, emphasis mine).

Much of the work on the consequences of the personal vote has focused on the behavior of legislators and specifically on the incentive that this electoral institution creates for differentiation. That is, when the electoral system generates an environment in which factors other than party typically influence the voters' selections, the individual candidates in this system have a strong incentive to provide the voters with alternate means to distinguish among them. One of the most common and most studied means for differentiation is that of creating a "home style" (Fenno 1978)

I am grateful to Lisa Baldez, Shaun Bowler, Matthew Shugart, Jessica Trounstine, and the anonymous reviewers for very helpful comments and suggestions. Thank you to Heidi Busche for outstanding research assistance.

Published by Cambridge University Press 1743-923X/13 \$30.00 for The Women and Politics Research Section of the American Political Science Association.

(C) The Women and Politics Research Section of the American Political Science Association, 2013 doi:10.1017/S1743923X12000700 
or an "electoral connection" (Mayhew 1974) in which a representative devotes substantial personal attention and resources to his/her constituency. Legislators and candidates also differentiate themselves using their previous electoral experience and/or their "local roots" (Ames 1995; Cain, Ferejohn, and Fiorina 1987; Carey 1997; Carey and Shugart 1995; Golden 2003; Katz 1980; Shugart, Valdini, and Suominen 2005). Scholars have concluded, therefore, that an electoral system in which there is an incentive for candidates to earn a "personal vote" will generate a heightened awareness of, and focus on, the candidates' unique personal traits, behaviors, and connections.

Such heightened awareness, however, may have unintended consequences for the diversity of the legislature. While many personal traits are relatively innocuous, there are several, such as a candidate's gender, race, ethnicity, or religion, that trigger powerful reactions in the minds of some voters. Thus, when the electoral system creates the incentive for voters to focus more on the personal traits of candidates, it may also allow any bias that those voters hold to manifest as decreased support for candidates from underrepresented groups. This article examines the effect of the personal vote on one form of diversity gender. I offer a large-N regression analysis of election results over twenty years to test the effect of the personal vote on women's representation and, using a combination of election results and survey data, find evidence that the presence of biased voters plus a personal vote is a recipe for underrepresentation. Further, I find that the existence of bias alone does not have a significant effect on the legislative representation of women. Instead, it is the interaction of the personalized electoral rules with the cultural context of bias that produces negative consequences for women's representation.

\section{THE PERSONAL VOTE: CONSEQUENCES FOR FEMALE CANDIDATES}

Contemporary literature addressing the consequences of the personal vote on women's legislative success is divided. Some scholars argue that voters, when given the opportunity of a personal vote in a proportional representation electoral system, will act in the interest of gender equality (Darcy, Welch, and Clark 1994; Kittilson 2006; Rule 1994). This line of reasoning is based on the assumption that the parties, not the voters, are the driving force behind the low numbers of women serving in 
legislatures. Thus, these scholars claim that when the electorate is given the option of a preference vote in a proportional representation electoral system (i.e., intraparty competition) they will, in the interest of equality, choose female candidates. But in their recent study of Ireland, McElroy and Marsh (2010) test for the effect of the personal vote in a proportional representation system and find no effect of this electoral environment on the success of female legislative candidates. They agree, however, that biased voters are not the cause of underrepresentation, stating that "voters do not discriminate against women even in an electoral environment that affords them this opportunity without any cost to their partisan preferences" (822).

In addition, some scholars have focused on how the personal vote affects female candidates in single-member district systems. ${ }^{1}$ This electoral system is often referred to as "winner-take-all" or "first-past-the-post," and, as its many nicknames signal, the votes and seats are not proportional. Instead, the candidate with the most votes wins the single seat up for election in the district, even if that candidate only wins a plurality of votes. One of the most well-known and accepted theories in the study of this electoral system is that when compared to proportional systems, majoritarian electoral systems have a negative effect on the representation of women in legislatures (Darcy, Welch, and Clark 1994; Matland 1993; Matland and Studlar 1996; Norris 1985; Rule 1981;1987).

While we can agree on and anticipate the effect of the majoritarian electoral system, the reason behind the effect is more ambiguous. One of the most common explanations is the zero-sum game scenario, which emphasizes the political risk a party takes by running a certain type of candidate in an environment where there can only be one winner. Darcy, Welch, and Clark (1994, 151) advance this argument:

The general statement of this argument is that women may be nominated in inverse proportion to the political risks involved [my emphasis]. Since the political risk to a party is less in a multimember district than in a singlemember, all-or-nothing district, in which a party risks losing everything, more women will be nominated in list PR, STV, and American- and British-style multimember district systems than in single-member district systems.

1. As noted in Carey and Shugart's typology, we cannot assume that all single-member district systems create an equal incentive to cultivate a personal vote. For example, one would expect a higher level of a personal vote in the United States because of the presence of primaries as the selection mechanism for candidates, versus that of the United Kingdom, where the selection decisions are centralized in the hands of party leaders. 
The "risk" of selecting female candidates, according to Darcy, Welch, and Clark, is created by the presence of voters who are prejudiced against women. These voters are less likely to vote for a woman than for a man of the same party, and thus running a woman becomes a more risky venture.

Matland (1993) finds similar results, arguing that the zero-sum nature of majoritarian systems with a district magnitude of one is the cause of underrepresentation in this system. He cites two reasons for this effect: First, from the perspective of the party, selectors would prefer men, who are more likely to have powerful intraparty connections and attachments to constituencies, in favor of running women, who may not have such connections. This first element of his explanation highlights the importance of constituency service and incumbency in a system with a personal vote. That is, experienced men have higher levels of constituency attachment, and this will have a negative effect on the willingness of parties to run their less-experienced women. The second element of his argument highlights the role of the personal vote as well, but from a different angle. Here, he asserts that "voters who might be hesitant to vote for a woman as their only representative may be more willing to vote for a woman as one of many candidates" (739, emphasis mine). This line of reasoning emphasizes that gender can be an important variable in the calculus of voters in this electoral system, which is exactly what one would expect from a system with a personal vote. Further, it entails a potential negative polarity of gender in such a context - that is, the assumption that a woman's gender will trigger voter "hesitancy" in this electoral environment and therefore work against her. Recent research by Thames and Williams (2010) supports this reasoning. In their test of the effect of the personal vote on the success of female candidates, they also argue that voters are less likely to vote for women due to prejudice against them, finding that the personal vote has a negative effect.

There are clearly mixed expectations for the effect of this electoral institution, but the common thread throughout these arguments is the role of bias against women. Those scholars who see the personal vote as having a positive or neutral effect tend to portray the voters as working in the interests of equality or, at the very least, seeing no difference between the abilities of male and female candidates. Those scholars who find a negative effect of the personal vote, however, depict the voters as biased - at best hesitant to vote for women, at worst prejudiced against them. The contradictions in the existing literature, therefore, are likely not due 
to differing expectations for the function of the personal vote, but rather in the scholars' perceptions and portrayals of the voters.

\section{PROPOSED THEORY: A CONDITIONAL EFFECT OF THE PERSONAL VOTE ON WOMEN}

In an effort to unify the existing literature on the personal vote, I offer a new approach. Rather than argue that the personal vote has a universal effect, I argue that the personal vote has a conditional effect that depends on the level of bias against female leaders in a society. In certain cultural environments, the personal vote has no effect on the success of female candidates. In others, however, it has a powerful negative effect on women's legislative representation. In short, we should not expect this electoral institution to have a consistent positive, negative, or neutral effect; the effect of the personal vote on women's representation varies by culture.

The key to understanding the differential effect of the personal vote, I argue, is found in the use of information shortcuts triggered by the "personal" nature of voting in such an electoral context. If a voter is able to employ information about the personal characteristics of a candidate in his/her decision calculus, then the voter will have the opportunity to use the sex of a candidate as an information shortcut. Information shortcuts, simply put, are cues or signals that the voters employ in place of being fully informed about each candidate. Continuing the line of reasoning that Downs (1957) began, scholars have argued that, while the party remains the most-used shortcut, voters can and do also use the personal traits and behavior of candidates as substitutes for full information (Conover and Feldman 1989; Popkin 1994). Because the sex of a candidate is one of the "cheapest" bits of information to gather (i.e., in most circumstances, a voter need only see a name - not even a picture is necessary to gain this information), it is an obvious response for the voter to utilize a gender stereotype to make a decision when offered the opportunity. Indeed, many scholars have found that voters draw inferences about personality traits, ideological stance, and policy priorities based on a candidate's sex (Alexander and Anderson 1993; Huddy and Terkildsen 1993; Koch 2000; Lawless 2004; Sanbonmatsu 2002).

The question becomes, therefore, when a voter makes inferences based on gender, are those inferences positive or negative? To answer that, one must consider the cultural context. For example, in a country such as Sweden, with its high levels of women's legislative representation, one would expect a shortcut based on gender to be relatively innocuous. Voters are accustomed to seeing women as effective leaders in 
government and the community, and, thus, most have updated their information shortcuts to reflect the fact that women's leadership abilities are equal to those of men. ${ }^{2}$ In addition, religious values and traditional ideals regarding women's "proper" place in the home and family are less important. Therefore, when given the opportunity to cast a personal vote, voters will operationalize the cue of "woman" very differently than, for example, voters in Brazil. There, due to the low number of female leaders and the relatively strong presence of religious/traditional values, women are more likely to be perceived as mother figures, unwilling or even unable to perform with equal skill in government as men (unless, of course, they are legislating on issues that fall squarely into the domestic sphere). That is, while voters in this cultural context may theoretically believe in gender equality, they are also more likely to believe that women do not have the personality traits necessary for good leadership. ${ }^{3}$ Information shortcuts based on gender in such a context, therefore, are more likely to have a negative effect on the success of female candidates.

Results from the World Values Survey offer evidence of significant differences in voter bias against female leaders. As Table 1 illustrates, citizens in all countries hold at least some level of bias against women's leadership ability. That said, the percentage of respondents who agree or strongly agree with the statement that "men make better political leaders than women do" varies dramatically by country. In some countries, such as Sweden, very few respondents (about $8 \%$ ) agree that men are better leaders. In the United States, about $25 \%$ of respondents agree. Further, in only two countries - Norway and Spain - do a majority of respondents "strongly disagree" with the statement. It seems clear, therefore, that we cannot assume a constant level of voter bias against women across the world.

\section{THE EFFECT OF THE PERSONAL VOTE ON WOMEN'S LEGISLATIVE REPRESENTATION}

I argue that because the presence of a personal vote increases the likelihood that voters will employ information shortcuts based on gender, this will, in

2. Beamen et al. (2009) offer an excellent analysis of the effect of the presence of female leaders on voters. Using the case study of India, they demonstrate that exposure to female leaders will, over time, decrease negative feelings toward them.

3. A rich literature demonstrates that idealized leadership traits are frequently gendered as male. A short list includes Aalberg and Jenssen 2007; Alexander and Andersen 1993; Fullagar et al. 2003; Huddy and Terkildsen 1993; Krueger et al. 2003; Lawless 2004; and Sanbonmatsu 2002. 
Table 1. World values survey results, by country. Percentage of respondents who believe that "men make better political leaders than women do"

\begin{tabular}{lcccc}
\hline Country & Agree Strongly & Agree & Disagree & Strongly Disagree \\
\hline Sweden & $1.4 \%$ & $6.3 \%$ & $51.3 \%$ & $40.9 \%$ \\
Peru & 2.3 & 15.2 & 71.1 & 11.4 \\
Canada & 3.1 & 15.2 & 57.7 & 24.0 \\
Norway & 3.3 & 11.2 & 22.7 & 62.8 \\
Netherlands & 3.4 & 14.2 & 49.0 & 33.4 \\
Switzerland & 3.5 & 12.1 & 46.5 & 37.8 \\
Australia & 3.7 & 20.9 & 57.6 & 17.7 \\
France & 3.8 & 17.4 & 33.7 & 45.1 \\
Finland & 3.9 & 15.1 & 54.8 & 26.3 \\
United Kingdom & 4.3 & 15.4 & 63.6 & 16.6 \\
United States of America & 4.4 & 20.3 & 57.0 & 18.3 \\
Spain & 4.9 & 15.8 & 29.0 & 50.3 \\
Argentina & 5.5 & 26.7 & 49.1 & 18.7 \\
Brazil & 5.9 & 25.8 & 53.6 & 14.7 \\
Poland & 10.5 & 32.8 & 47.0 & 9.7 \\
Bulgaria & 13.9 & 34.0 & 39.7 & 12.5 \\
Romania & 15.0 & 40.0 & 26.2 & 18.8 \\
South Africa & 15.6 & 35.0 & 33.4 & 16.0 \\
Czech Republic & 16.3 & 34.4 & 39.5 & 9.8 \\
Chile & 17.6 & 31.7 & 34.4 & 16.3 \\
Latvia & 22.7 & 43.2 & 31.7 & 2.4 \\
Slovakia & 26.9 & 40.8 & 25.7 & 6.6 \\
Estonia & 28.7 & 40.5 & 24.7 & 6.1 \\
\hline
\end{tabular}

Source: World Values Survey 1981-2008 Official Aggregate v.20090901, 2009. World Values Survey Association (www.worldvaluessurvey.org). Aggregate File Producer: ASEP/JDS, Madrid. Due to the data restrictions, this table presents the WVS results for only those election years included in the analysis.

some cultural contexts, advantage male candidates. In other cultural contexts, however, I expect the personal vote to have no effect on women's legislative representation, and in still others, it could conceivably benefit female candidates; the effect of this institution depends on how voters use the "information" of gender when they are faced with a female candidate. To test for this differential effect of the personal vote, I collected data from 23 democracies. ${ }^{4}$ The unit of

4. The countries were chosen based on the following criteria: First, only those countries that Freedom House (www.freedomhouse.org) ranked as fully free in their assessment of political rights and civil liberties; second, only those states in which the World Values Survey was completed within five years of the election. Due to these requirements, the data set excludes certain legislative elections results for a small number of states for years in which the state was either not a democracy (e.g., election results from pre-2001 Peru are excluded) or if the WVS did not collect data for that period of time (e.g., the survey question used by this analysis was asked in France only in the year 2006. Thus, following these criteria, only the legislative elections from the years after 2001 are included). Due to 
analysis is the legislative election by country, and the dependent variable is the percentage of seats in the lower house won by women at each legislative election over the past twenty years.

I coded one of the key independent variables in this analysis - the personal vote - using an ordinal scale. ${ }^{5}$ The scale I employ is based on the classification system created by Carey and Shugart (1995) and thus employs three factors to capture the level of the personal vote: ballot composition, vote pooling, and the number/level of votes. Ballot composition refers to the level of control by party leadership over which candidates are selected to be on the ballot. Vote pooling captures whether votes are pooled across the party - that is, the level to which voting for a particular candidate contributes to the success of the party as a whole. And number/ level of votes highlights the importance of the number of votes a voter may cast, as well as whether there is intraparty competition. Carey and Shugart rated countries on a scale of $0-2$ for each factor; the cumulative total represents the country's personal vote score. ${ }^{6}$ The scale ranges from $0-6$; 0 is the lowest level of personal vote and 6 is the highest. ${ }^{7}$ Although not perfect, this widely-recognized scale provides a consistent, clear method for tracking the presence of the personal vote across countries. Table 2 presents all of the cases included in this analysis; the average representation of women in each of the legislatures over time; the scores on ballot, pool, and vote variables; and the total personal vote score.

In order to test for the predicted differential effect of the personal vote on the legislative success of women, the other key independent variable in this analysis is an interaction of the personal vote scale and a variable chosen to capture that society's level of bias against female candidates. Operationalizing bias is difficult, but the World Values Survey offers a solid method for tracking at least basic levels of prejudice against female leaders. In both the 1996-1998 and 2005-2006 waves, the WVS asked respondents to agree/disagree with this statement: "Men make better political leaders than women do." Clearly, the respondents who "agree"

these constraints, certain legislative elections were not included for the following states: Czech Republic, Estonia, France, Latvia, Netherlands, Peru, Slovakia, Switzerland, and United Kingdom.

5. In addition, I ran a model in which the personal vote is coded as a dichotomous variable. The findings from that model match those presented here.

6. A detailed explanation of coding is presented in Appendix I.

7. Ideally, this scale would include the effect of district magnitude as well (Carey and Shugart 1995; Shugart, Valdini, and Suominen 2005), but its differential effect makes it quite challenging to integrate. In addition, while we know the effect of magnitude depends on the list type, we have yet to determine exactly how powerful that effect is. Thus, it seems most appropriate to exclude the effect of district magnitude rather than risk overstating (or understating) its power. 
Table 2. Average percentage of women in legislature and personal vote scale, 1990-2010, by country

\begin{tabular}{lccccc}
\hline Country & $\begin{array}{c}\text { Average Women in } \\
\text { Legislature } 1990-2010\end{array}$ & Ballot & Vote & Pool & $\begin{array}{c}\text { Personal Vote } \\
\text { Scale }\end{array}$ \\
\hline Brazil & $7.7 \%$ & 2 & 2 & 0 & 4 \\
Romania & 10.2 & 0 & 0 & 0 & 0 \\
Chile & 12.0 & 1 & 2 & 0 & 3 \\
Latvia & 12.5 & 1 & 2 & 0 & 3 \\
United States & 13.4 & 2 & 1 & 2 & 5 \\
Estonia & 15.3 & 0 & 0 & 1 & 1 \\
France & 15.4 & 0 & 1 & 0 & 1 \\
Czech Republic & 16.0 & 1 & 1 & 0 & 2 \\
Slovakia & 16.0 & 1 & 1 & 0 & 2 \\
Poland & 17.4 & 1 & 2 & 0 & 3 \\
Bulgaria & 18.4 & 0 & 0 & 0 & 0 \\
Australia & 19.1 & 1 & 1 & 1 & 3 \\
United Kingdom & 20.0 & 0 & 0 & 0 & 0 \\
Canada & 21.6 & 0 & 0 & 0 & 0 \\
Peru & 22.7 & 1 & 2 & 0 & 3 \\
Switzerland & 27.2 & 1 & 1 & 0 & 2 \\
Spain & 29.0 & 0 & 0 & 0 & 0 \\
Argentina & 33.0 & 0 & 0 & 0 & 0 \\
South Africa & 33.9 & 0 & 0 & 0 & 0 \\
Netherlands & 37.0 & 1 & 2 & 0 & 3 \\
Finland & 37.7 & 2 & 2 & 0 & 4 \\
Norway & 37.9 & 0 & 0 & 0 & 0 \\
Sweden & 42.3 & 1 & 2 & 0 & 3 \\
\hline
\end{tabular}

Sources: Inter-Parliamentary Union (www.ipu.org); Carey and Shugart (1995); Electoral Studies "Notes on Recent Elections."

Notes: Due to data restrictions, some legislative elections have been excluded from the data set. Also, in 2008, Romania reformed its electoral system. The coding in the table represents the electoral system before 2008, but the full database reflects the change.

are the very people one could imagine allowing the sex of a candidate to negatively influence their vote; they would then select a male candidate over a female candidate in an electoral context with a personal vote. Thus, Bias refers to the percentage of respondents who agree with the above statement, and Bias \& Personal Vote is the interaction of the country's personal vote scale and level of bias against female leaders. ${ }^{8}$

The remaining variables in the analysis function as controls - that is, other variables that the literature on representation has demonstrated to

8. There are two waves of WVS survey data used in this analysis: 2005-2006 wave and 1996-1998 wave. Not all countries were included in both waves, and thus only those elections that occurred within five years of the survey date were included in this data set. 
have an effect on women's electoral success: the percentage of votes cast for left-wing parties, executive ideology, district magnitude, presence of a gender quota law, presence of voluntary party gender quotas, proportional representation electoral system, strength of religion in society, the Human Development Index, years since women's suffrage was achieved, and regional dummies designed to pick up regional differences that the other variables did not capture (all coding methods are available in Appendix II).

In an effort to examine whether the effect of the personal vote is conditional upon bias, I performed an OLS regression with robust standard errors clustered by country. Further, because these are time series data, I corrected for autocorrelation using a trend variable. In addition, the distribution of the residuals does not signal heteroskedasticity. Two models are presented in Table 3. Model 1 does not include the interaction effect of bias and personal vote; both of these variables are included, but they are not interacted. Model 2 is the full model, including the interaction term.

Model 1 demonstrates that the effect of the personal vote alone does not reach conventional levels of significance. But Model 2 reveals that the reason why the personal vote fails to achieve significance in Model 1 is due to the differential effect of this variable. That is, the presence of the personal vote has a conditional effect on the percentage of women in the legislature, and the effect depends on the level of bias against female leaders. These results also demonstrate that bias alone does not have a significant effect on the legislative representation of women, highlighting the fact that electoral rules are critical. The electoral institution is what triggers the bias to manifest as detrimental to women's legislative success. It is, in short, the combination of bias and the personal vote that creates the effect on representation.

Given that interacted variables are not easily interpreted (Kam and Franzese 2007), I present these results graphically in Figure 1. ${ }^{9}$ This graph demonstrates that at low levels of bias (i.e., when relatively few respondents agree that men make better political leaders than women), the presence of a personal vote does not have a significant effect on the electoral fortunes of female candidates. At a low level of bias (i.e., one standard deviation below the mean), the effect of the

9. This graph was created using GRINTER, a STATA utility for graphing the marginal effect of an interacted variable in regression models, Vl. 5. For more information, see the website of Frederick J. Boehmke: http://works.bepress.com/frederick_boehmke/80/(December 28, 2012). 
Table 3. OLS regression coefficients (and robust standard errors) predicting the percentage of female legislators

\begin{tabular}{|c|c|c|}
\hline & \multicolumn{2}{|c|}{ Percentage of Female Legislators } \\
\hline & Model 1 & Model 2 \\
\hline Personal vote & $\begin{array}{r}-1.06 \\
(0.88)\end{array}$ & $\begin{array}{c}1.82 \\
(1.45)\end{array}$ \\
\hline Bias & $\begin{array}{r}-0.09 \\
(0.12)\end{array}$ & $\begin{array}{c}0.10 \\
(0.18)\end{array}$ \\
\hline Bias \& Personal Vote & & $\begin{array}{c}-0.14^{*} \\
(0.06)\end{array}$ \\
\hline Executive ideology & $\begin{array}{c}-0.60 \\
(1.15)\end{array}$ & $\begin{array}{c}-0.16 \\
(1.05)\end{array}$ \\
\hline Left-wing votes & $\begin{array}{r}-0.09 \\
(0.06)\end{array}$ & $\begin{array}{r}-0.08 \\
(0.06)\end{array}$ \\
\hline District magnitude & $\begin{array}{c}0.01 \\
(0.02)\end{array}$ & $\begin{array}{c}0.01 \\
(0.02)\end{array}$ \\
\hline Quota law & $\begin{array}{l}3.03 \\
(3.33)\end{array}$ & $\begin{array}{c}3.48 \\
(2.79)\end{array}$ \\
\hline Party quota & $\begin{array}{r}-1.66 \\
(2.49)\end{array}$ & $\begin{array}{c}-0.21 \\
(2.29)\end{array}$ \\
\hline Proportional representation & 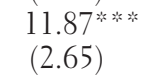 & $\begin{array}{l}12.59 \text {. } \\
(2.34)\end{array}$ \\
\hline HDI & $\begin{array}{l}6.14 \% \\
(3.61)\end{array}$ & $\begin{array}{l}6.59 \% \\
(3.33)\end{array}$ \\
\hline Religion & $\begin{array}{r}-0.10^{*} \\
(0.05)\end{array}$ & $\begin{array}{r}-0.08 \\
(0.06)\end{array}$ \\
\hline Suffrage & $\begin{array}{c}0.08 \\
(0.07)\end{array}$ & $\begin{array}{l}0.14 \% \\
(0.06)\end{array}$ \\
\hline Scandinavia & $\begin{array}{l}8.16^{\text {\% }} \\
(3.80)\end{array}$ & $\begin{array}{l}5.95 \% \\
(3.47)\end{array}$ \\
\hline Post-Communist & $\begin{array}{c}-5.51 \\
(4.32)\end{array}$ & $\begin{array}{r}-4.48 \\
(4.44)\end{array}$ \\
\hline Latin America & $\begin{array}{c}0.14 \\
(5.73)\end{array}$ & $\begin{array}{c}1.47 \\
(5.48)\end{array}$ \\
\hline Africa & $\begin{array}{l}30.60 \text {; } \\
(8.85)\end{array}$ & $\begin{array}{l}34.70 \text {. } \\
(9.47)\end{array}$ \\
\hline Trend (year of election) & $\begin{array}{c}0.26 \\
(0.16)\end{array}$ & $\begin{array}{c}0.14 \\
(0.17)\end{array}$ \\
\hline Constant & $\begin{array}{l}13.89 \\
(8.05)\end{array}$ & $\begin{array}{c}6.38 \\
(7.93)\end{array}$ \\
\hline $\mathrm{N}$ & 102 & 102 \\
\hline Adjusted $\mathrm{R}^{2}$ & 0.834 & 0.852 \\
\hline
\end{tabular}

Note: Levels of significance: ${ }^{*} \mathrm{p}<.10 ;{ }^{* *} \mathrm{p}<.05 ;{ }^{* * *} \mathrm{p}<.01$

personal vote is .006 and is not significant at conventional levels. In other words, when about $12 \%$ of respondents agree with the statement that men are better leaders than women (for example, as in Norway), 


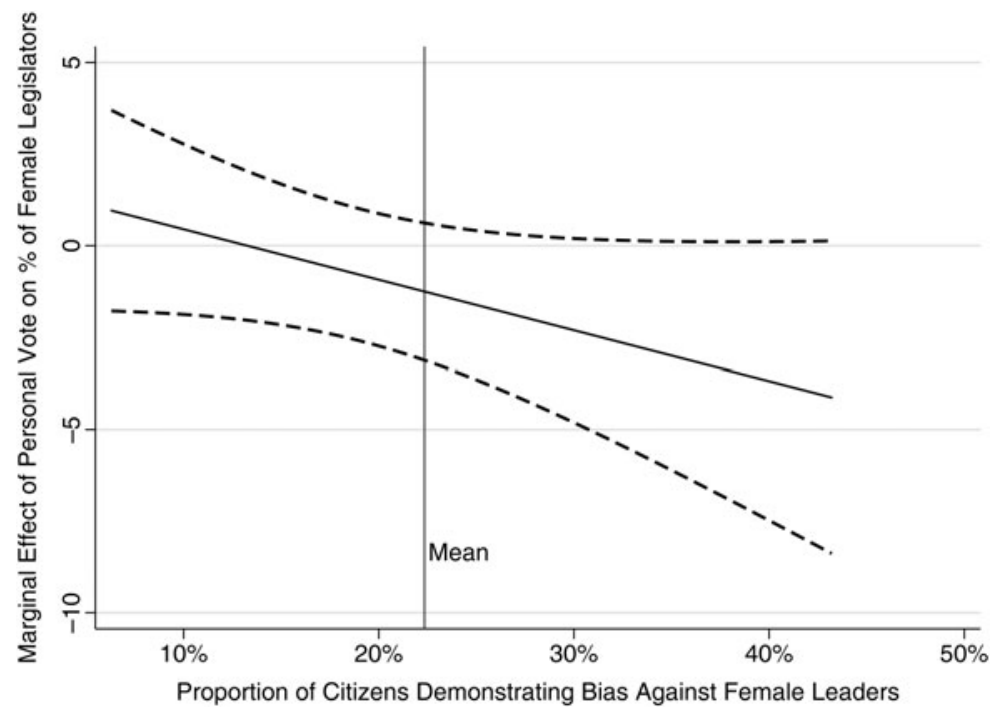

Figure 1. Effect of personal vote on percentage of female legislators, by bias.

the presence of a personal vote has no effect on the electoral success of women.

As the level of bias against female candidates increases, however, the personal vote begins to have a statistically significant and negative effect on the likelihood that women will be elected. At a high level of bias (one standard deviation above the mean), the effect of the personal vote is -2.51 , and is significant $(\mathrm{p}<.05)$. In other words, when about $32 \%$ of citizens agree that men are better leaders (for example, as in Poland), the personal vote has a powerful and significant negative effect on the likelihood that women will be elected to the legislature. These results provide support for the hypothesized differential effect of the personal vote. In a cultural context where there are fewer negative traits associated with women and where women's leadership is more accepted, the presence of a personal vote has no effect. But when bias against female leaders is prevalent, personalizing the election tends to have a detrimental effect on the success of female candidates. It is interesting to note that there is no evidence of a positive effect of the personal vote on women's legislative fortunes. That is, even when bias is quite low, the effect of this institution is neutral, but not positive. 


\section{CONCLUSION}

A wide variety of polities, from Kenya to the United Kingdom, are engaged in negotiations to change their legislative electoral systems, and thus research in this area is critical to providing information on the expected consequences of reform. Without this research, citizens may be unaware of the costs and benefits of a new electoral system, and, even more troubling, decisions may be made based on misinformation. A particularly disconcerting example of this is from the Citizens' Assembly on Electoral Reform, a group of constituents in British Columbia chosen to research and select a replacement for the existing legislative electoral system. They released a report in 2004 that asserted that an electoral reform that created a personal vote would be positive for legislative diversity. In their report - which was sent to every household in British Columbia - they offered the following explanation:

BC-STV increases choices, allowing voters a much greater say in determining who will be their local representatives. It allows voters to choose between candidates and parties, it lets voters show which candidates they prefer and in what order, and it ensures that their preferences count. This will provide increased opportunities for candidates from underrepresented groups [emphasis mine]. ${ }^{10}$

The assumption underlying this claim is that voters are not prejudiced against members of underrepresented groups, and further, that they actually may be biased in favor of them. In this cultural context, therefore, the expectation is for a positive effect of the personal vote. Using a multicountry regression analysis, I provide evidence that we should not assume a positive effect of the personal vote on the diversity of the legislature, even under conditions of low bias. Instead, the conditional effect of the personal vote is either neutral or negative for women's representation, depending on the level of bias against female leaders in the cultural context of the election. Thus, while it may be valuable to increase the choices given to voters as well as the connections between legislators and their constituents, one should not expect that a benefit of the personal vote is increased diversity in the legislature. On the contrary, if there is substantial bias against female

10. Citizens' Assembly on Electoral Reform. 2004. "Making Every Vote Count: The Case for Electoral Reform in British Columbia," British Columbia: Library and Archives Canada. Final Report: Page 7. 
leaders in a society, then the personal vote allows this bias to manifest as fewer votes for female candidates.

\section{REFERENCES}

Aalberg, Toril, and Anders Todal Jenssen. 2007. "Gender Stereotyping of Political Candidates." NORDICOM Review 28 (1): 17-32.

Alexander, Deborah, and Kristi Andersen. 1993. "Gender as a Factor in the Attribution of Leadership Traits." Political Research Quarterly 46 (3): 527-45.

Ames, Barry. 1995. "Electoral Strategy under Open-List Proportional Representation." American Journal of Political Science 39 (2): 406-33.

Beamen, Lori, Chattopadhyay Raghabendra, Esther Duflo, Rohini Pande, and Petia Topalova. 2009. "Powerful Women: Does Exposure Reduce Bias?” Quarterly Journal of Economics 124 (4): 1497-540.

Cain, Bruce, John Ferejohn, and Morris Fiorina. 1987. The Personal Vote: Constituency Service and Electoral Independence. Cambridge: Harvard University Press.

Carey, John M. 1997. "Institutional Design and Party Systems: Aggregate and Individual Level Effects." In Consolidating the Third Wave Democracies: Themes and Perspectives, eds. Larry Diamond, Marc F. Plattner, Yun-han Chu, and Hungmao Tien. Baltimore, MD: Johns Hopkins University Press, 67-92.

Carey, John M., and Matthew S. Shugart. 1995. "Incentives to Cultivate a Personal Vote: A Rank Ordering of Electoral Formulas.” Electoral Studies 14 (4): 417-39.

Conover, Pamela Johnston, and Stanley Feldman. 1989. "Candidate Perception in an Ambiguous World: Campaigns, Cues, and Inference Processes.” American Journal of Political Science 33 (4): 912-40.

Darcy, Robert, Susan Welch, and Janet Clark. 1994. Women, Elections, and Representation. Lincoln: University of Nebraska Press.

Downs, Anthony. 1957. An Economic Theory of Democracy. New York: Harper Collins Publishers.

Fenno, Richard F. 1978. Home Style: House Members in their Districts. New York: Longman Publishing Group.

Fullagar, Clive J., H. Canan Sumer, Magnus Sverke, and Renee Slick. 2003. "Managerial Sex-Role Stereotyping: A Cross Cultural Analysis." International Journal of Cross Cultural Management 3 (1): 93-107.

Golden, Miriam. 2003. "Electoral Connections: The Effects of the Personal Vote on Political Patronage, Bureaucracy and Legislation in Postwar Italy." British Journal of Political Science 33 (2): 189-212.

Huddy, Leonie, and Nayda Terkildsen. 1993. "Gender Stereotypes and the Perception of Male and Female Candidates." American Journal of Political Science 37 (1): 119-47.

Kam, Cindy, and Robert J. Franzese. 2007. Modeling and Interpreting Interactive Hypotheses in Regression Analysis. Ann Arbor: University of Michigan Press.

Katz, Richard S. 1980. A Theory of Parties and Electoral Systems. Baltimore, MD: Johns Hopkins University Press.

Kittilson, Miki Caul. 2006. Challenging Parties, Changing Parliaments: Women and

Elected Office in Contemporary Western Europe. Columbus: The Ohio State University Press.

Koch, Jeffrey W. 2000. “Do Citizens Apply Gender Stereotypes to Infer Candidates' Ideological Orientations?” Journal of Politics 62 (2): 414-29. 
Krueger, Joachim I. , Julie F. Hasman, Melissa Acevedo, and Paola Villano. 2003. "Perceptions of Trait Typicality in Gender Stereotypes: Examining the Role of Attribution and Categorization Processes." Personality and Social Psychology Bulletin 29 (1): 108-16.

Lawless, Jennifer L. 2004. "Women, War, and Winning Elections: Gender Stereotyping in the Post-September $11^{\text {th }}$ Era." Political Research Quarterly 57 (3): 479-90.

Matland, Richard E. 1993. "Institutional Variables Affecting Female Representation in National Legislatures: The Case of Norway." Journal of Politics 55 (3): 737-55.

Matland, Richard E., and Donley T. Studlar. 1996. "The Contagion of Female Candidates in Single-Member District and Proportional Representation Electoral Systems: Canada and Norway." The Journal of Politics 58 (3): 707-33.

Mayhew, David. 1974. Congress: The Electoral Connection. New Haven, CT: Yale University Press.

McElroy, Gail, and Michael Marsh. 2010. "Candidate Gender and Voter Choice: Analysis from a Multimember Preferential Voting System." Political Research Quarterly 63 (4): 822-33.

Norris, Pippa. 1985. "Women's Legislative Participation in Western Europe." Western European Politics 8 (4): 90-101.

Popkin, Samuel L. 1994. The Reasoning Voter: Communication and Persuasion in Presidential Campaigns. Chicago: The University of Chicago Press.

Rule, Wilma. 1994. "Parliaments of, by, and for the People: Except for Women?" In Electoral Systems in Comparative Perspective: Their Impact on Women and Minorities, eds. Wilma Rule and Joseph F. Zimmerman. Westport, CT: Greenwood Press, 15-30.

_ 1987. "Electoral Systems, Contextual Factors, and Women's Opportunity for Election to Parliament in Twenty-three Democracies." Western Political Quarterly 40 (3): 477-98.

- 1981. "Why Women Don't Run: The Critical Contextual Factors in Women's Legislative Recruitment." Political Research Quarterly 34 (1): 60-77.

Sanbonmatsu, Kira. 2002. "Gender Stereotypes and Vote Choice." American Journal of Political Science 46 (1): 20-34.

Shugart, Matthew Soberg, Melody Ellis Valdini, and Kati Suominen. 2005. "Looking for Locals: Voter Information Demands and Personal Vote-Earning Attributes of Legislators under Proportional Representation." American Journal of Political Science 49 (2): 437-49.

Thames, Frank C., and Margaret S. Williams. 2010. "Incentives for Personal Votes and Women's Representation in Legislatures." Comparative Political Studies 43 (12): $1575-1600$.

\section{APPENDIX I}

\section{Carey and Shugart (1995) Method for Estimating Presence of Personal Vote}

Ballot

$0=$ Leaders present a fixed ballot, and voters may not disturb list.

$l=$ Leaders present party ballots, but voters may disturb list.

$2=$ Leaders do not control access to ballots or rank.

Pool

$0=$ Votes are pooled across whole party.

$l=$ Votes are pooled at the subparty level.

$2=$ No vote pooling. 
Votes

$0=$ Voters cast a single vote for one party.

$1=$ Voters cast votes for multiple candidates.

$2=$ Voters cast a single vote below the party level (i.e., intraparty competition).

As Carey and Shugart note, this coding method produces an ordinal scale. Higher scores signal an increased level of personal vote incentives, while lower scores signal relatively few incentives for voters to cast a personal vote.

\section{APPENDIX II}

\section{Coding Methodology and Sources of All Variables in the OLS Regression (Table 3)}

Executive Ideology: Ideology on left/right scale of executive elected or sitting at time of legislative election. Coded as Left $=1$, Right $=0$.

Left-wing Votes: The percentage of votes cast in legislative election for parties on left wing of ideological spectrum. Coded as Left $=1$, Right $=0$. District Magnitude: Average district magnitude for country at time of legislative election.

Quota Law: Dichotomous variable: If there is an electoral law or constitutional amendment in the country that requires gender quota compliance (1) or not (0). Source: http://www.quotaproject.org/index.cfm Party Quota: Dichotomous variable: If any party in the country employed a voluntary quota (i.e., a gender quota created and "enforced" voluntarily from within the party) (1), or not (0). Source: http://www.quotaproject. org/index.cfm

Proportional Representation: Dichotomous variable: Refers to whether the electoral system is proportional (1) or majoritarian (0).

Trend (Year of Election): Trend variable that captures the passage of time. HDI: Composite index that measures a country's average achievements in three basic aspects of human development: health, knowledge, and a decent standard of living. Health is measured by life expectancy at birth; knowledge is measured by a combination of the adult literacy rate and the combined primary, secondary, and tertiary gross enrollment ratio; and standard of living by GDP per capita (PPP US\$). For ease of interpretation, coded in this data set as HDI*10- Mean of HDI*10 (mean HDI of countries in data set $=.9033450704$ ). Source: http://hdr. undp.org/en/reports/

Religion: Results from survey question from World Values Survey. This is the percentage of respondents who replied that religion is "very 
important" in life. Source: World Values Survey 1981-2008 Official Aggregate v.20090901, 2009. World Values Survey Association (www. worldvaluessurvey.org). Aggregate File Producer: ASEP/JDS, Madrid.

Suffrage: The number of years that women in the state have had full voting equality with men. Source: Women in Parliaments 1945-1995: A Statistical Survey, published by the Inter-Parliamentary Union Geneva: 1995.

Bias: Results from survey question from World Values Survey. This is the percentage of respondents who "strongly agreed" with the statement that men make better political leaders than women do. Source: World Values Survey 1981-2008 Official Aggregate v.20090901, 2009. World Values Survey Association (www.worldvaluessurvey.org). Aggregate File Producer: ASEP/JDS, Madrid. 